\title{
Balkanologie
}

Balkanologie Revue d'études pluridisciplinaires

Vol. IX, n $1-2 \mid 2005$

Volume IX Numéro 1-2

\section{Preachers of God and martyrs of the Nation}

The politics of murder in ottoman Macedonia in the early $20^{\text {th }}$ century Pasteurs de Dieu et martyrs de la nation : la politique du meurtre en Macédoine ottomane au début du XX $X^{e}$ siècle

\section{Basil C. Gounaris}

\section{OpenEdition}

Journals

Édition électronique

URL : http://journals.openedition.org/balkanologie/573

DOI : 10.4000/balkanologie.573

ISSN : 1965-0582

\section{Éditeur}

Association française d'études sur les Balkans (Afebalk)

\section{Édition imprimée}

Date de publication : 1 décembre 2005

ISSN : $1279-7952$

Référence électronique

Basil C. Gounaris, «Preachers of God and martyrs of the Nation », Balkanologie [En ligne], Vol. IX, n 1-2 | 2005, mis en ligne le 13 janvier 2010, consulté le 17 décembre 2020. URL : http://

journals.openedition.org/balkanologie/573; DOI : https://doi.org/10.4000/balkanologie.573 


\title{
PREACHERS OF GOD AND MARTYRS OF THE NATION THE POLITICS OF MURDER IN OTTOMAN MACEDONIA IN THE EARLY 20th CENTURY
}

\author{
Basil C. Gounaris*
}

Terror was not an exceptional phenomenon either in Macedonia or in any other part of the $19^{\text {th }}$ century Ottoman Empire. It was a practise exercised by everybody that felt strong enough to resist or to escape reprisals. Christian peasants and pastoralists fell easy prey to brigands, bashibazouks, and gendarmes or to the regular army itself whenever it was convenient to any of these predators. Warfare of every kind or the threat of warfare multiplied such occasions. Mobilised and armed men simply could not resist the temptation of plundering, looting and sacking their fellow Christian peasants. It was the closest battlefield to reach, the easiest victory to achieve, and the most remunerative campaign to fight. Many times such practices also involved murder, violation, or kidnapping for ransom. Yet there were no high politics behind this terror, at least until the Armenian massacres of 1896 . It was a fact of life, a lengthy process related to the social and economic disintegration of the Ottoman Empire.

\section{THE POLITICS OF TERROR}

There is no doubt that the politics of terror and indeed of murder were introduced to Macedonia by the Bulgarian revolutionary committees in the late $1890^{1}$. Whatever their members - known in Turkish as the comitadjis - had

\footnotetext{
'Department of History and Archaeology, Aristotle University of Thessaloniki, Greece. E-mail : vkg@hist.auth.gr.

$[\mathrm{g}]$ means references are in greek.
}

${ }^{1}$ Cf. Perry (Duncan), The Politics of Terror. The Macedonian Revolutionary Movements, 1893-1903, Durham : Duke University Press, 1988. 
in mind about the future of Macedonia, certainly Greeks and Serbs were not part of it. This exclusive character might not be that clear in the many revisions of their constitutions but it was quite evident in practice ${ }^{2}$. What all the committees and their fractions had in common was the silent backing of the Bulgarian Exarchic Church, a fact hardly ever mentioned in the IMRO ${ }^{3}$ literature. It was not a formal alliance and far for from being a peaceful co-existence. It was "unholy" in many ideological aspects but still a strategic necessity. Joining the Exarchate and abandoning the Ecumenical Patriarchate was not simply a symbolic gesture for an individual or a community. According to the $10^{\text {th }}$ article of the 1870 firman establishing the Bulgarian Exarchate, a majority of two thirds was a precondition for any bishopric to shift its allegiance to this new institution. In the 1890 s, such shift was an important political decision and the Committees knew it. It was the first step on the way to Sofia, or else, a clear sign of opposition to Constantinople, Athens, and Belgrade. Apparently and quite understandably, in the case of peasant communities, especially in the disputed middle-zone of Macedonia, streching to the South of Ohrid, Kroushevo, Strumitsa and Melnik and to the North of Kastoria, Edessa (Voden), Yanitsa, and Serres, this step was more important and practical than the dubious digestion of socialism. This zone crossed no less than nine bishoprics, which had been claimed as Bulgarian in 1866 but had been left out the Exarchic jurisdiction in 1870 and of the Bulgarian Principality in 1878 .

Of course the committees did not plan to murder all those who opposed the Exarchate. It was not necessary. The General Regulations introduced by the Porte in the late 1860 s in the context of the Tanzimat reform scheme had assisted the secularisation of community administration and certainly the in troduction of some democratic principles. Bishops could no longer impose their will unchallenged. As a result of this innovation and for multiple other social and economic reasons opposition parties had grown at every Macedonian village. The absence of influential and indisputable notables especially in the chiflics - maximised domestic tension. All Committee leaders had to do was to manipulate this tension by recruiting a rising Greek or Bulgarian-educated elite, who did not wish to go back to the fields and become tenant farmers like their forefathers. Such men, on many occasions descen-

\footnotetext{
2 For a brief account of all the material I have used, see Panayotopoulou (Anna), From Thessaloniki to Krousevo : Ideology, Organisation and Activities of IMRO, 1893-1903 [g], Aristotle University of Thessaloniki : unpublished MA thesis, 1993, where all the available Bulgarian sources are cited.

3 The Internal Macedonian-Adrianopolitan Revolutionary Organisation (IMRO) was established in Thessaloniki in 1893 . IMRO had had a troubled relationship with the other major Bulgarian Committee, the Supremists, founded (1895) and based in Sofia, varying from brotherly co-operation to open clash.
} 
dants of priests, if given arms, would not hesitate to use calculated violence in order to win the majority and redirect the politics of their communities4.

What "calculated violence" means is obvious from two British reports drawn in 1900 : the former lists all the murders committed since the year 1894 by the Bulgarians on Orthodox-Greek inhabitants of the vilayet of Thessaloniki and the latter the murdered Serbs since 1897. In a total of 66 cases of assault, seventeen were against landed proprietors, mostly village notables, twelve against educational personnel, eleven against priests $(16,6 \%)$ and four against merchants 5 . Obviously the selection of targets was not random. It is quite safe to guess that some Greek and Serbian priests and notables had resisted Bulgarian penetration more vigorously than expected. Since teachers were socially involved with or related to notables and clergymen and their appointment was viewed as an indication of national loyalties, they were also classified as primary targets.

The scale of violence in the early years of the twentieth century was unprecedented. No less than 200 people were murdered between January 1901 and August 1903. Then it got worse. Even if we exclude the victims of the Ilinden uprising (i.e. those killed between August and November 1903) as well as the members of the Greek and Bulgarian bands - to the extent that this is possible since many of them were locals - still the death list is extremely long. According to the British annual reports on political crime, no less than 3.300 murders were committed in the following 56 months (an average of almost 60 deaths per month) by Bulgarian, Greek, Romanian and Serbian activists as well as by state forces ${ }^{6} .600$ more were assassinated in the period between the revolt of the Young Turks and the Balkan wars. $10 \%$ of the victims were of unknown national preference ; $53 \%$ were classified as Bulgarians, $33.5 \%$ as Greeks. Romanians and Serbs as a whole were no more than $3,5 \%$. In some 750 cases, the occupation of the victim is known : Priests and notables represented roughly a $30 \%$. Considering their social status, it is not likely that there were many more of them among the 3360 cases of unknown occupation. Therefore it could be argued that they represented a rough $5 \%$ of all fatal assaults in a twelve-year period. Among these victims were some 100 priests of various ranks, $2 / 3$ of them Greek-Orthodox.

4 See Gounaris (Basil c.), "Social Cleavages and National "Awakening" in Ottoman Macedonia ", East European Quarterly, 29 (4), 1995 and Agelopoulos (Georgios), " Perceptions, Construction, and Definition of Greek National Identity in Late $19^{\text {th }}$ - Early $20^{\text {th }}$ Century Macedonia ", Balkan Studies, 36 (2), 1995.

5 Public Records Office, FO 195/2089, attached to Biliotti's report, (38), 20 April 1900, ff. 128-133.

6 This statistic is based on the electronic data-base of the Museum of the Macedonian Struggle in Thessaloniki. Its main sources are the British annual reports found at the Public Records Office, series FO195. 


\section{THE CLERICAL TARGETS}

Apparently the escalation of violence had reduced the percentage of selected clerical targets over the total death toll from 16,6 to some $2,5 \%$. The percentage of clergymen registered in the official Greek list of veterans of the 19031908 struggle is of the same scale. Still it looks to me relatively high, considering that priests, monks, and other Church officials could not have represented more than the actual $1 \%$ of the Christian population. However, the questions asked in this paper go beyond the quantification of the losses that clergy suffered in Macedonia. They seek to explain in particular, more than their violent death, the involvement of village vicars and priests in the Greek-Bulgarian national struggle in terms of community politics and irregular warfare.

Priests in Macedonian villages were not different from their flock. They were peasants and lived like peasants. More often than not, priesthood was hereditary. It secured an extra-income of unknown size, a position of some authority amongst the village notables, and the role of the go-in-between their community and the local bishop. Such relation would be a useful asset for the ordination of a son or a nephew when the old priest died. The appointment of a member of his family as the village teacher was also a possible favour. As a rule preachers were not illiterate but of course there were many exceptions : men of refined knowledge who widely travelled like Papa-Stavro Tsami, the vicar of the Vlach-speaking village of Pisoderi or completely ignorant like so many priests in the miserable malaria stricken chiflicks of the plains. Occasionally priests served also as community teachers but in the early twentieth century this practise was rather exceptional since there was no shortage of academy graduates, sponsored by various nationalist societies and indeed by the Balkan Foreign Ministry budgets7.

The infiltration of the Exarchate into the Southern parts of Macedonia multiplied the positions of Church officials of every kind. According to an estimate in 1891 in the region of Kastoria, only 13 out of 53 villages had abandoned the Patriarchate and in the region of Bitola 24 out of 100 . In 1896, the figures had risen to 26 and 42 respectively ${ }^{8}$. Exarchic communities, according to their size and power, demanded rotating services, built their own churches, occupied one of the existing or even the main village church, if they could. If they were outnumbered, they simply restricted themselves to the small churches of the graveyards. In any case, new priests were ordained unless the serving

7 Cf. Vouri (Sofia), Education and Nationalism in the Balkans. The Case of NW Macedonia 1870-1904 [g], Athens : Paraskinino, 1992.

${ }^{8}$ FO195/1849, "Shipley to Blunt, Monastir, 31 March.1894", ff. 103-107 and "Blunt to Currie, Thessaloniki, 20 April 1894 ",f. 86. 
- running the risk of getting out of business or getting killed - opted for the Exarchate. If no compromise could be reached, then the Ottoman authorities had the power to seal the disputed church 9 . Needless to say this was not a decision easy to reach because the Exarchic Church since 1872 was an unholy schismatic institution anathematised by the Patriarch. Moreover the introduction of relative democratic principals in the administration of the community did not necessarily imply a free vote. Some families, especially large zadrugas, landed proprietors, shop-keepers, retailers, those who paid most of the taxes, hired labourers, sponsored the school, and knew the Ottoman administration could exercise influence disproportional to their actual number. They were the local patrons. Had it not been for the presence of armed bands probably they would have dominated rural areas and have made it much more difficult for the Exarchate to prevail. But guns changed the situation utterly. Nationalism and revolutionary ideas created a new relentless elite of high-school graduates and ambitious migrants ready to take over administration at all cost. Just a handful of them could put an official claim on any church and eventually achieve, if not rotation, then interruption of services by Turkish intervention ${ }^{10}$.

Priests were caught in between and neutrality was not an option. If the decision was for the Exarchate, then they were expected to sign the relevant petition to the authorities and to start praising the Exarch instead of the Patriarch in all services. Obviously they could not stay idle ; in fact, their energetic support was considered indispensable either way. Such decisions were not easily taken, especially if a community could not reach it on its own will. In that case, the procedure was almost standard. A Bulgarian band would enter the village at night, pay a visit to the priest, summon the villagers in the church, and initiate them to their new "national faith". It would then ask the priest, the mayor, and the council members to sign their declaration and the seal keeper (muchtar) to stamp it. If they had time they would also ask all the priests together to perform the Exarchic service in order to commit them fully to the new cause and expose them in public ${ }^{11}$. There was no middle-way. PapaTale, reverend and teacher of Greek at the village Sirbsi, was killed on the spot when he refused to put up the band of voevoda Sougaref in March $1903^{12}$. In the village of Sklithro (Zelenits), even a priest from Peloponnisos (Southern

\footnotetext{
9 For a rather detailed account of such events see the study by Dakin (Douglas), The Greek Struggle in Macedonia 1897-1913. Thessaloniki : Institute for Balkan Studies, 1966.
}

${ }^{10}$ Alexandris (Alexis), ed., The Archive of National Martyr Bishop of Smyrna Chrysostomos [g], Athens : MIET, 2000, vol.1 (Drama 1902-1910), Pp. 20-22.

\footnotetext{
${ }^{11}$ Karavangelis (Germanos), "The Struggle for Macedonia. Memoirs ", in The Penelope Delta Archive of the Struggle for Macedonia. Memoirs [g], Thessaloniki : IMXA, 1984, p. 11 ; Dragoumis (Ion), The Note-Books of Ilinden [g], Athens : Ekdoseis Petsivas, 2000, p. 62. Several petitions of this kind can be found in Bulgarian Academy of Sciences, ed., Macedonia. Documents and Material, Sofia, 1978, document n ${ }^{\circ} 111$, pp. $571-589$.
}

12 Dragoumis (Ion), op.cit., p. 66. 
Greece) had been "convinced" to join the Bulgarian Church"13. When Greek bands appeared on the scene, shortly before Ilinden, they followed the very same practise, sometimes in the encouraging presence of bishop of Kastoria, Germanos Karavangelis, a young Greek clergyman famous for his nationalist fervour and the tough handling of his enemies ${ }^{14}$. Any Patriarchist bishop, whenever the Greeks regained control of a village, could dismiss the Exarchic priest, if he had been ordained by a schismatic bishop ${ }^{15}$.

Even at the gunpoint joining the schismatic Church was not an easy decision for people notorious for their attachment to tradition. Yet in dogmatic terms and worship practices peasants could hardly say the difference. The overwhelming majority of them could not even understand the services at all, either in Church Slavonic or in Hellenistic Greek. Neither their piety was at risk nor were their religious practises, especially if the old and the new priest were the same individual. In terms of politics, however, the difference was paramount since after the declaration had been signed the village was expected to accommodate Greek or Bulgarian bands, prepare a local militia and special hides for gun, men, and ammunition, furnish reliable messengers and reserve food. In return most members of the "national committee" would receive financial support or even monthly salaries as high as one Turkish pound ${ }^{16}$. Village priests were expected to be not simply a part of this network but at the very hard core of it.

Some were indeed hard-core nationalists and this was not a matter of threat or reward. It had to do with their stubborn character, sound national education, family history, and the backing they had secured from their allies inside the community and the bands in the vicinity. Papa Stavros Tsamis was a regular informer of the Greek Consulate in Bitola and a valuable liaison for the Greek bands. This is why he was murdered with an axe in August $1906^{17}$. His colleague, the priest of Variko (Mocren), a "staunch Bulgarian", had a narrow escape when he was ambushed in February 1905 on his return from Kastoria by a band led by an ex voevoda from Vasiliada (Zagoritsani), who had joined the Greek side ${ }^{18}$.

There is evidence that priests had even killed with their own hands their predecessors or their competitors. This was the case of the Exarchic priest pop-

\footnotetext{
${ }^{13}$ Karavangelis (Germanos), op.cit., p. 27.

14 Ibid.

15 Chrysostomos (Kalafatis), op.cit. p. 21.

16 Tsondos-Vardas (Georgios), The Struggle for Macedonia [g], Athens : Ekdoseis Petsivas, 2003, vol. 1 (Diary 1904-1905), p. 30.

${ }^{17}$ For an uneven view of Papa-Stavros by its enemies see Sonnichsen (Albert), Confessions of a Macedonian Bandit, New York : Duffield, 1909, chapter XXII.
}

${ }^{18}$ Tsondos-Vardas (Georgios), op.cit., pp. $87-88$. 
Nikola in the village of Perikopi (Prekopana) on Mt Vitsi, who killed his predecessor, papa-Christo, in July 1903. It was also the case of Papa-Elia, the aged Greek-Orthodox priest of Velousina. Papa-Elia had a small parish of only seventeen houses, the rest of his village being Exarchic. He would toll the bell, gun in hand, and assemble his flock one by one. With the same gun he wounded seriously his Exarchic colleague but the latter, quite unexpectedly, recovered. Papa-Elia knew that revenge was soon to come, so he invited repeatedly Greek bands to give a pre-emptive strike to his opponents in the village of Optitsar in the outskirts of Bitola. He failed to convince the band of Karavitis in July 1905 but he succeeded to attract the daring band of Makris in the spring of $1906^{19}$. He led the band himself to Optitsar but started to shake when they approached the enemy village. When he refused to proceed he was lifted and carried by the fighters and left just outside the village. The band entered the village, arrested eight men, and brought them to the priest to identify them. Papa-Elias still shaking refused even to see them. He closed his eyes, covered his face, and begged not to be presented. Makris assured him that he was running no risk for his life for these Bulgarians where not going to see anyone else, at least not in this world ${ }^{20}$.

Indeed murders were unlikely to happen if retaliation was to follow soon. This is why the band of Pavlos Melas rushed to kill the murderer priest of Perikopi ${ }^{21}$. In the village of Mesimeri, when the Graecoman (i.e. fanatic Greek) priest Papa-Stoyan was murdered by a Bulgarian band in February 1905, the villagers themselves pressed Akritas ${ }^{22}$, a Greek bandleader, to revenge his death or they would leave the Patriarchate. They convinced him in May 1905 to murder an Exarchic priest, Pop-Gotse Stoichef, who had shifted sides for money, on his Sunday visit to the local monastery ${ }^{23}$. As a rule in Macedonia no side could secure a region to the extent that was necessary to deter enemy initiatives. Therefore in most cases such murders were likely to initiate a new circle of retaliation. In 1901, when the Bulgarians murdered the seventy-year-old

19 Karavitis (Ioannis). The Struggle for Macedonia. Memoirs [g], Athens : Ekdoseis Petsivas, 1994, vol.1, pp. $344-345$.

20 Makris (Georgios-Dikonymos), "The Struggle for Macedonia. Memoirs ", in The Penelope Delta Archive of the Struggle for Macedonia. Memoirs (op.cit.), pp. 151-152.

${ }^{21}$ Meln (Matalia), ed., Pavlos Melas [g], Athens : Dodoni, 1964, p. 390. Melas was the first Greek officer killed in action in Macedonia. He was the perfect apostle of Hellenism in Macedonia but his performance as a chieftain was rather poor. His father-in-law was Stephanos Dragournis, ex-Foreign Minister and his brother-in-law was Ion Dragounis, Secretary at the Greek Consulate in Bitola, both strongly involved in the Macedonian affairs.

22 Second-Lieutenant Konstandinos Mazarakis-Ainian had already served as military attache at the Greek Consulate General in Thessaloniki.

23 Mazaradods-Ainian (K.), "The Struggle for Macedonia. Recollections ", in The Struggle for Macedonia. Memoirs [g], Thessaloniki : IMXA, 1984, pp. 249-250. 
papa-Dimitri of Asprogeia (Strebeno), bishop Karavangelis ordained his twenty year old son and encouraged his nephew Vangelis, a man of impressive statue, to revenge his uncle's murder ${ }^{24}$. In another case, when papaKonstandinos of Polypotamos (Nered) was murdered in 1902, his son was ordained in his place and was renamed Konstandinos. It was not long before the young priest became the new target of IMRO. Few weeks before Ilinden, he evacuated his family to Florina and himself left for Athens carrying a reference letter from Ion Dragoumis, secretary of the Greek Consulate in Bitola ${ }^{25}$. He was soon to return to his post and become involved. In October 1904, he informed Melas and his men that three bands of comitadjis were sheltered in his village and led the Greeks to their hide ${ }^{26}$. The new priest of Kratero (Rakovo), "a clean-cut young man" was also the son of the late priest killed by the Bulgarians. Therefore he did not hesitate to present himself on his own will and offer his services to the band of Vardas (nom-de-guerre of Lieutenant Georgios Tsondos), who had succeeded Melas in the leadership of Greek bands in Western Macedonia ${ }^{27}$.

Not all of the priests were prepared to stand up and die for a cause. When the band of Kaoudis, a tough Cretan, met the priest of Triandafylia (Lazen) in late August 1904, the latter started to pray. He narrated the misfortunes of his village, and eventually he confessed to the chieftain : " Even myself, I pretend to be a Bulgarian. During the service loudly I honour the Exarch but whispering in my prayers I praise the Patriarch. Only God knows what's in my soul " ${ }^{28}$. He then became a regular informer of the Greek side. In fact, his case looks more representative of the average priest attitude, for the simple reason that it was flexible and less risky. On another occasion, when the band of Korakas entered Nestorio (Nestram) in the region of Kastoria, the chieftain asked the priest who headed the welcome committee : "Are you Greek or Bulgarian ? You joined the Exarchate under pressure, you even accepted a Bulgarian teacher. (...) Tomorrow they will go for your houses, wives, and children ? Why didn't you take guns in hand ? Aren't you Christians ? Aren't you Greeks ? ". The priest responded with caution : « Master, how dare you break our hurts by calling us Bulgarians ? Now that you are here we shall go together to the monastery and "Christianise", and we shall even take guns, if we need to. (...) Meanwhile please leave the village, for if Mitro the Vlach - notorious for his

\footnotetext{
${ }^{24}$ Karavangelis (Germanos), art.cit., p. 21.

${ }^{25}$ Dragoumis (Ion), op.cit., p. 171. Ion Dragoumis, of Macedonian origin himself, was a pioneer of the Greek organisation in NW Macedonia.

${ }^{26}$ Karavitis (Ioannis), op.cit., pp. 110-111.

${ }^{27}$ Tsondos-Vardas (Georgios), op.cit,, vol.2/1 (Diary 1906), p. 234.

${ }^{28}$ Gounaris (Vasilis K.), ed., The Autumn of 1904 in Macedonia. The Unpublished Diary of Euthymios Kaoudis [g], Thessaloniki : Mouseio Makedonikou Agona, 1992, p. 30.
} 
cruelty - is informed for your presence here, we are doomed to death $n^{29}$. Korakas left but other chieftains were less tactful with priests. The ruthless papa-Drakos, an armed priest born in Eastern Romelia and a true giant in size, a follower of Makris, used to shake and curse any timid priest they met in Macedonia and ask them loudly : "What kind of priest are you ? Why on earth do we keep you up here ? ". The threat was too open to neglect ${ }^{3 \circ}$.

As a rule Greek chieftains of every kind were fully aware of the precarious situation in Macedonian villages. Torture and death was a penalty that IMRO would not hesitate to implement upon Graecoman activist priests, especially if they were stigmatised as turncoat adventurers. They have seen that happen many times. So threat had to be calculated and flavoured with some praise and, most of all, with encouragement. Vardas, found suitable the occasion of a common service at the Monastery of Dragos, few days before Christmas 1906, to deliver an enthusiastic speech to an assembly of seven priests ${ }^{31}$. Another time, having criticised severely the reverend of Touholi for his undue fear, he advised him to go to open-market of Nestorio, wonder around, and show to everybody that "times had changed" and he was no longer afraid of the Bulgarians ${ }^{32}$. From the voluminous diaries of Vardas it becomes clear that tolerance and encouragement secured profitable co-operation with numerous Patriarchist priests who were used extensively as organisers, agents of every kind, messengers, informers, hosts of bands. Their effectiveness or incompetence was not necessarily related to their loyalty or dishonesty but their most important contribution, after all, was simply retaining their posts. And this was not guaranteed. If they were terrified, they were bound to leave and settle in Kastoria, Florina or any other major town, like so many Patriarchist priests had done in $1903^{33}$. The aforementioned papa-Dimitri of Asprogeia, ordained by Karavangelis in the place of his murdered father, fled to the nearby town of Lehovo when the Bulgarians burnt his house and controlled his village in early $1905^{34}$. Priesthood was welcomed as a hereditary right but martyrdom was too heavy a burden to carry. Vardas knew well that even Vlach-speaking PapaStavros, a national hero par-excellence and eventually a martyr, could neither break-up his relations with his pro-Romanian acquaintances and relatives nor abstain from any service they participated 35 . Yet he was valuable.

29 Stavropoulos (Vasileios), "The Struggle for Macedonia. Memoirs ", The Struggle for Macedonia. Memoirs (op.cit.), pp. 402-403.

${ }^{30}$ Makris (Georgios-Dikonymos), art.cit., p. 91 ; cf. Tsondos-Vardas (Georgios), op.cit., vol. 1, p. 53.

${ }^{31}$ Tsondos-Vardas (Georgios), op.cit., vol.1, pp. 365-367.

32 Ibid., p. 200.

33 Cf. Dragoumis (Ion), op.cit., pp. 24, 542.

34 Tsondos-Vardas (Georgios), op.cit., vol.1, p. 95.

35 Tsondos-Vardas (Georgios), op.cit., vol.2/1, p. 54. 
Valuable and energetic priests who were prepared to risk their lives acquired special privileges as members of the new local national elite or committees. This was a fact for both camps. Some became treasurers and used state money to finance their next of keen instead of the village network ${ }^{36}$. Others tried to exploit their national contribution to settle personal or professional disputes in their favour 37 . There is also strong evidence that a few priests used their close links with the bands to blackmail their local opponents, regardless of their religious affiliation. They threatened and in many cases they managed to accuse them as national enemies in order to achieve their murder by bandsmen, without risking revenge themselves ${ }^{38}$. Given the fluidity of loyalties and the perplex network of relations it was not particularly difficult to expose anyone. Indeed it seems there was no standard way to nominate priests or other individuals as imminent targets. Bandleaders had to relay on pouring information from other priests, the local bishop, and various national committees. They had to check thoroughly any accusation before issuing orders for murder but this, due to serious difficulties in communication, was not always easy. The case of papa-Vasili of Flambouro (Negovani) is typical. Accusations that he was a traitor were pilling up but Vardas kept on wondering whether all this evidence was circumstantial ${ }^{39}$.

In some cases there was no hesitation. Papa-Yanni of Agiochori (Gratsan) near Drama had been "adviced" repeatedly to review his loyalty to the Patriarche and let his village join the Bulgarian side. Since he ignored all warnings, he was stubbed to death a summer night of $1906^{\circ}$. Papa-Tirpo of Ieropigi (Kostenets) toped the list of Vardas targets. The Greeks knew that he had been the official representative of the Exarchate in Kastoria, a close friend of the notorious voevoda Vasil Tsakalarof and the protagonist in his village decision to join the Bulgarian cause ${ }^{41}$. He had to die. Papa-Stamatis Tanchef was the black-beard impressive vicar of the Exarchic Church in Thessaloniki, the "biting heart" of the Bulgarian movement. Everybody suspected that he was a Bulgarian officer in clandestine operation $4^{2}$. He was a difficult target, however,

${ }^{6}$ Ibid., p. 70.

${ }^{37}$ Ibid., pp. 274-275.

$3^{8}$ Ibid., p. 33 .

39 Tsondos-Vardas (Georgios), op.cit, vol.2/2 (Diary 1907), pp. 1000-1027.

$4^{\circ}$ Chrysostomos, op.cit., pp. 99-100.

$4^{1}$ Dragoumis (Ion), op.cit., p. 62 ; Tsondos-Vardas (Georgios), op.cit., vol.2/1, pp. 55, 137.

$4^{2}$ Zannas (Alexandros), "The Struggle for Macedonia. Recollections " in The Struggle for Macedonia. Memoirs (op.cit.), p. 84 ; Mazarakis, op.cit., p. 202. 
since he was always under armed escort. Alexandros from Aivali, the least suspected executioner, accomplished the deadly mission. He was a young man of French education and socialist orientation who simply could not resist the glory of priest killing ${ }^{43}$. Makris, a Cretan, in his memoirs recalled with pride the night he set an ambush at Lissolai and killed thirteen Bulgarians, among them two priests, two teachers and one voevoda 44 . On another occasion a prominent member of the Greek committee threatened to resign because the assassination of the Bulgarian priest of Emporio had not been assigned to his own trusted executioners. The local chieftain replied that there were plenty of heroic deeds to be accomplished but it looks that no venture could match the glory of killing activist priests 45 . It was a stock that was not easily replaceable. When the pro-Serbian priest of Virbiani at the kaza or Prilep was murdered in February 1903, the General Consul of Serbia went himself to the village to investigate the incident ${ }^{46}$. Serbian clergy was in short supply in Macedonia.

As far as Greeks were concerned, village priests were the second of the two pillars indispensable for irregular warfare and national indoctrination. The second was the network of monasteries all around Macedonia. No less than 25 of them were located in Western Macedonia, some on the natural routes that bands followed to intrude Turkish territory. It was a Patriarchist domain where the Exarchate had slim chances to recruit followers ; the Bulgarian monastery at $M$ t Athos being the only exception in the littoral part of Macedonia. Monasteries in the highlands were the best-stocked and comfortable hides. Since the life of women and children was not endangered, bands would not hesitate to ask shelter in their premises as many times as they had to. It is hard to decide whether bandsmen were welcome indeed. There is plenty of evidence that some abbots, even at the Greek side of the border, were reluctant to take side or to jeopardise the welfare of the monastery. They had been exhausted by the frequent visits of brigands and they wanted to be left in peace. It took them some time to adjust themselves to the fact that these new brigands were fighting for a cause. In most cases, however, Greek bands were hosted with generosity and fervent enthusiasm and this is testified by the frequent and fierce Bulgarian attacks that monasteries suffered. Some incidents are better known than others : in March 1905. were destroyed the monasteries of Sliven and Tsirilovo; in August 1905, the Monastery of Lissolai ; in January 1906, the Monastery of the Holy Trinity near Pisoderi ; in March 1907, the Monastery of Ossani. They were all strategic targets of considerable importance, which had to be neutralised.

43 Mazarakis-Ainian (R.), art.cit., pp. 206-207.

44 Makris (Georgios-Dikonymos), art.cit., pp. 141-142.

45 Tsondos-Vardas (Georgios), op.cit, vol.1, p. 146.

$4^{6}$ Dragoumis (Ion), op.cit., p. 14. 


\section{CONCLUSION}

The politics of terror in Macedonia is a story more complicated than it looks at first sight. The death of activists was eventually useful to all sides. Assassins rejoiced and boasted for the death of their worst enemies. The camp which had suffered losses tried to profit the most out of its misfortunes by taking pictures of the tortured bodies and compiling lists of martyrs to be forwarded to consular offices and newspaper agents everywhere in the world. Then it started to organise revenge of an equal scale. At a lower level, however, it was a civil war between fellow villagers, whose petty-politics and social cleavages of every kind had been indissolubly mingled with the high politics of the Macedonian Question.

In any case, this first round, before 1912, was a war for souls rather than territories, as it has been repeated many times, therefore priests could not abstain $^{47}$. On this, there was consent. Arguing for the Exarchate or, to be precise, against the least popular of the local bishops, was easier than preaching nationalism or socialism to peasants. It was also convenient to all the Bulgarian Committees. Detachment from the Patriarchate was imperative regardless of the final solution of the Macedonian Question. It was a good start for them. On the other camp, the appointment of young, educated and energetic bishops like Germanos Karavangelis in Kastoria, Ioakeim Foropoulos in Bitola, and Chrysostomos Kalafatis in Drama, all in the early 19oos, testifies that the Patriarchate had eventually decided to side with the forces of Greek nationalism in order to safeguard its valuable Macedonian bishoprics. Therefore its crew, village priests, was mobilised, although in theory the Patriarchate was against the ecclesiastical segregation of "races" 48 .

The list of the deceased is far from complete but the fact still remains that assassinated Greek-Orthodox priests and notables (especially seal-keepers) outnumbered their Exarchist counterparts roughly by two to one. This reflects the offensive character of the Bulgarian committees and the early start they have had. Until late 1904, hardly any Exarchist priest had been killed compared to twenty Patriarchists. In 1907, casualties were equal. It also proves that, in terms of figures and impression, the Greek bands cancelled half of what Bulgarians achieved in the southern parts of Macedonia. The total death toll that clergy suffered in almost ten years of struggle clearly proves that conquering the souls of priests by force was not an easy matter. Despite the para-

47 Livanios (Dimitris), " "Conquering the Souls" : Nationalism and Greek Guerrilla Warfare in Ottoman Macedonia, 1904-1908 ", Joumal of Byzantine and Modern Greek Studies, 23, 1999.

$4^{8}$ Kofos (Evangelos). " Patriarch Joachim III (1878-1884) and the Irredentist Policy of the Greek State ", Journal of Modern Greek Studies, 4 (2), 1986. 
mount symbolic importance of the actual assassination, indeed it was counterproductive. The extensive use of violence exercised by the Committees to the equal benefit of the Bulgarian Exarchate proved detrimental for both of them. In the era of romantic nationalism the army of Patriarchist dead priests, true martyrs of the nation, was invincible. 